\title{
Correlation of FXIII Val34Leu Polymorphism with Decreased Risk of Myocardial Infarction in Egypt
}

\author{
Hatem Al-Kordy A. Amin ${ }^{1 *}$, Mohamed I. Kotb-El-Sayed ${ }^{1}$, \\ Abdullah A. Hashish ${ }^{3}$, Faten M. Mohamed ${ }^{2}$, Hanaa F. Abdel Aziz ${ }^{3}$ \\ and Ola F. Leheta ${ }^{3,4}$ \\ ${ }^{1}$ Biochemistry and Molecular Biology Department, Faculty of Pharmacy, Helwan University, \\ Ain Helwan, Helwan P.O. Box 11790, Cairo, Egypt. \\ ${ }^{2}$ Physiology Department, Faculty of Medicine, Suez Canal University, Ismailia, Egypt. \\ ${ }^{3}$ Clinical Pathology Department, Faculty of Medicine, Suez Canal University Hospital, Suez \\ Canal University Ismailia, Egypt. \\ ${ }^{4}$ College of Medicine, King Saud University, Saudi Arabia.
}

\section{Authors' contributions}

This work was carried out in collaboration between all authors. Authors HKA and OFL designed the study. Authors HKA and HFA wrote the manuscript and managed the literature searches. Authors HKA, MKE and AAH performed the genotyping analysis. Authors OFL, HFA and FMM collected the recruited subjects, cardiac diagnosis data from cardiologists and performed clinical chemistry tests. Authors HFA and MKE performed the statistical analysis. All authors read and approved the final manuscript.

\section{ABSTRACT}

Aim: Factor XIII is a transglutaminase that crosslinks fibrin in the last steps of the coagulation process. A few polymorphic sites have been identified in this gene, one of them being a point mutation (FXIII Val34Leu), leading to an amino acid change of valine to leucine. Several studies were published on the association between FXIII 34Leu allele and a decreased incidence of myocardial infarction (MI) with high controversy results dependent on the population. The aim of our study was to further investigate the possible protective role of the FXIII 34Leu allele polymorphism against acute MI in Egyptian patients. 
Study Design: Clinical examination by cardiologist specialists, blood test for biochemical markers and DNA genotyping using specific molecular sensing probes in Real Time PCR.

Place and Duration of Study: Patients were recruited from consecutive admission to the coronary care unit, Suez Canal University Hospital, Ismailia, Egypt.

Material and Methods: Total 107 subjects were recruited and subdivided into two main groups; patients (82) and control group (25). On admission, the following data were fulfilled: age, smoking, history of Diabetes Mellitus (DM) and Hypertension (HTN), family history of Ml. Clinical examination: Blood pressure and Body Mass Index calculation were done and for patients a short outcome prognosis was done using left ventricular Ejection Fraction (EF). Routine laboratory investigations for recruited groups including fasting and postprandial glucose level, Triglycerides, total Cholesterol, HDL-C and LDLC were carried out. Factor XIII Val34Leu was genotyped for all the recruited subjects using site specific molecular probes in real time PCR.

Results: Obtained data were analyzed using $\mathrm{OD}$ and $\mathrm{Cl}$ values, Pearson correlation coefficient Inter-correlations and Regression analysis model that showed insignificant association between FXIII Val34Leu polymorphism and MI patients.

Conclusion: FXIII 34Leu variant has no association with reduced incidence of myocardial infarction in Egyptian patients.

Keywords: Factor XIII Val34Leu genetic polymorphism; transglutaminase; acute myocardial infarction; Egypt.

\section{ABBREVIATIONS}

AP: Activated peptide; Arg37 and Gly38: Arginine 37 and Glycine 37; CAD: Coronary artery disease; CVD: Cardiovascular disease; Cys311: Cysteine 311; FBG: Fasting blood glucose; FXIII: Factor III; MI: Myocardial infarction; PCR: Polymerase chain reaction; SNPs: Single nucleotide polymorphisms; Val34Leu: Valine34 Leucine.

\section{INTRODUCTION}

Several subsequent studies confirmed a positive association between plasma levels of coagulation factors and the risk of arterial cardiovascular diseases (CVDs) [1]. Most myocardial ischemic events occur through plaque ruptures that precipitate the formation of an occluding thrombus [2]. The growth and stability of a thrombus may be affected by an increased activity of the coagulation system or a decreased activity of the fibrinolytic system [3]. Factor XIII (FXIII) is a protransglutaminase which plays a pivotal role in the coagulation process by cross-linking fibrin in the final stages of blood coagulation and facilitating the resistance to fibrinolysis. It circulates as a heterotetramer composed of two $A$ and two $B$ subunits. The 731 amino acid A subunits contain the active site cysteine, while the 661 amino acid $B$ units serve as carrier proteins. FXIII is activated by thrombin, which cleaves the peptide bond between arginine (Arg37) and glycine (Gly38) of the A subunit and releases a 37 amino acid amino-terminal activation peptide (AP). The presence of fibrin accelerates the activation of FXIII by thrombin. In the presence of calcium, the A subunit dimer then dissociates from the $B$ subunits and undergoes a conformational change that exposes the active site (Cysteine 311, which is found within the sequence Tyrosine-GlycineGlutamine-Cysteine-Tryptophan). Activated factor XIII (FXIIIa) catalyzes the formation of the $\gamma$-glutamyl- $\varepsilon$-lysine peptide bonds between the $Y$ and $\alpha$ chain in non-covalently bound fibrin polymers. FXIIla also incorporates the adhesive proteins, fibronectin and thrombospondin 
and the antifibrinolytic protein, $\alpha$-2-antiplasmin, into the fibrin clot via similar linkages. The net result is a stable clot that is relatively resistant to shear forces and fibrinolysis. In addition to its role in blood coagulation, FXIII also contributes to extracellular matrix remodeling, tissue repair, wound healing and in maintaining pregnancy and cell adhesion and migration. Occlusion of the artery leading to ischaemia and myocardial injury is usually caused by potent thrombus formation and clotting in which blood coagulation factor XIII (FXIII) is involved by cross-linking fibrin molecules in the clot stabilizing it and producing resistance [48].

Myocardial infarction (MI) represents the end-point of a genetically complex disease and its development and progression underlies interactions between environmental and genetic influences [9]. As described by Lane and Grant [10]. Genetic polymorphism is considered a strong indicator of disease risk when mediated through a phenotype and a positive family history [9]. The FXIII gene has several common single nucleotide sequence variations, which encode amino acid substitutions. The gene coding for the FXIII-A subunit is located on chromosome 6p24-25, spanning 160 kilobases $(\mathrm{kb})$ and consists of 15 exons interrupted by 14 introns encoding a mature protein of 731 amino acids [11].

Five common coding polymorphisms have been identified in the FXIII-A subunit: Val34Leu, Tyr204Phe, Pro564Leu, Val650lle and Glu651Gln. A common $G$ base to $T$ base polymorphism in exon 2 of the FXIII-A subunit gene (Val34Leu) causes a valine-to-leucine change at position 34; three amino acids upstream from the thrombin cleavage site. However, the thrombotic role of this polymorphism is controversial and might be specific to populations. This polymorphism exists in approximately $20 \%$ of white European, $40 \%$ of Pima Native American, $13 \%$ of South Asian, $2.5 \%$ of Asians, $28.9 \%$ of Blacks, $44.3 \%$ of Caucasians, $51.2 \%$ of Amerindians populations [12-17]. The 34Leu allele is virtually absent in the Japanese population and present in 11-27\% in Australian Caucasians [18].

The aim of our study is analyzing genetic polymorphism of FXIII 34Leu allele in Myocardial infarction (MI) Egyptian patients and detect any possible associations in-between and assessing the protective effect (if any) of this polymorphism.

\section{PATIENTS AND METHODS}

Patients were recruited from consecutive admission to the coronary care unit, Suez Canal University Hospital, Ismailia, Egypt.

A-Priori test was performed to identify the requested numbers of subjects in each group using anticipated effect size (Cohen's d) (0.6), Desired statistical power level (0.8) and Probability level (0.05). The obtained calculations were Minimum total sample size (twotailed hypothesis) (90).

The recruited subjects (total 107) were subdivided into two main groups; patients (total 82) and control group (total 25). On admission, the following data were fulfilled for all recruited groups: age, smoking, history of Diabetes Mellitus (DM) and Hypertension (HTN), family history of $\mathrm{Ml}$ and stroke. Clinical examination: Blood pressure examination and Body Mass Index (BMI) calculation were carried out and for patients a short outcome prognosis was done using left ventricular Ejection Fraction (EF).

Routine laboratory investigations for all recruited groups including fasting and postprandial glucose level, Triglycerides, total Cholesterol, high density lipoprotein (HDL-C) and low 
density lipoprotein (LDL-C) were carried out using Hitachi 912 auto-analyzer (Roche Diagnostics GmbH. Str. Mannheim, Germany).

\subsection{Myocardial infarction Diagnosis and FXIII (Val34Leu) Polymorphism Genotyping}

Diagnosis of patients with acute $\mathrm{Ml}$ was carried out by cardiologist consultants in the University cardiology clinic and based on full history taking, clinical examination, resting ECG, cardiac enzymes and echocardiography. MI was defined either by presence of STSegment Elevation (STE) or depression (non-STE) at the J-point $\geq 1 \mathrm{~mm}$ in two or more contiguous leads, In leads V2 and V3, $2 \mathrm{~mm}$ of ST elevation in men and $1.5 \mathrm{~mm}$ in women was required, new left bundle branch block or development of pathologic $Q$ and a rise and/or fall in cardiac troponin with at least one value above the $99^{\text {th }}$ percentile of the upper reference limit (troponin I levels $>0.1 \mathrm{ng} / \mathrm{mL}$ ) and elevated CK-MB is enzyme $[19,20]$.

Hyperlipidemia was defined as total Cholesterol $>220 \mathrm{mg} / \mathrm{dL}$, Triglycerides $>150 \mathrm{mg} / \mathrm{dL}$ or treatment with lipid lowering drugs. Diabetes was defined as patients with random glycemia $>200 \mathrm{mg} / \mathrm{dL}$ at admission or FBG $>125 \mathrm{mg} / \mathrm{dL}$ in two determinations or receiving insulin or oral hypoglycemic drugs; hypertension was defined as repeated blood pressure $\geq 140 / 90$ $\mathrm{mmHg}$ or previous treatment with antihypertensive drugs [21].

Genomic DNA was extracted from peripheral blood leucocytes using silica membrane based DNA purification method (Qiamp DNA blood kit, Qiagen, Germany). Real time Polymerase Chain Reaction (PCR) Rotor-GeneTM 6000 (Corbett Research, Mortlake, NSW, 2137, Australia) was used for FXIII Val34Leu genotyping. Primers 5'AAC/TTC/CAG/GAC/CGG/CTT/T-3' and (5'-ACC/CAG/AGT/GGT/GGG/GAA-3') were used yielding $97 \mathrm{bp}$ amplicon. Two TaqMan probes were designed and used (5'-FAMCAGTGGAGCTTCAGGGCTTGGT-Tamra-3') for T-allele and (5'-TETCAGTGGAGCTTCAGGGCGTGGT-Tamra-3') for G-allele. PCR reaction mixture consisted of $0.1 \mu \mathrm{g}$ of DNA; QPCR master mix provided from Qiagen, Germany was used. $400 \mathrm{nM}$ from each primer and $150 \mathrm{nM}$ from each probe were added in final $25 \mu \mathrm{l}$ reaction volume. PCR cycles were optimized as follow: $95^{\circ} \mathrm{C}$ for $16 \mathrm{~min}$. for initial enzyme activation and DNA denaturing; 40 cycles $\left(95^{\circ} \mathrm{C}\right.$ for $30 \mathrm{sec}$., $68^{\circ} \mathrm{C}$ for $60 \mathrm{sec}$ ).

\subsection{Statistical Analysis}

Collected data were coded, entered and analyzed using the Rotor gene instrument analysis software version 1.7 build (87). Data were exported into Statistical Package for the Social Sciences (SPSS version 10.0) software for analysis. Baseline characteristics of the study population were presented as frequencies and percentages (\%) in qualitative data or mean values and standard deviations (SD) in quantitative data. Differences between frequencies were compared by Chi-square or Fisher exact tests. Differences between means were compared by paired samples t tests. A $P$ value of $=0.05$ was considered significant. Quantitative ranking of risk factors in the studied patients was performed by odds ratio (OR) and confident interval. Pearson correlation coefficient test was used after controlling of age variable to correlate the dependent variable FXIII (Va/34Leu) genotypes and other independent variable (predictors). Analysis Of Variance (ANOVA) test followed by logistic regression analysis model of the dependent variable and other studied variables (independent predictors) were performed to estimate the effect of the FXIII (Val34Leu) polymorphism. Logistic regression with adjustment for age and sex was performed on each 
variable to estimate $\mathrm{OR}$ and $p$-value. Consistency of the observed genotype frequencies with Hardy-Weinberg equilibrium was done.

\section{RESULTS}

This study illustrated a significant difference between MI patients group and control group in SBP, DBP, FBS, Cholesterol, LDL, TG and HDL (Table 1).

Table 1. Descriptive statistics of the studied control and patients

\begin{tabular}{|c|c|c|c|c|c|c|}
\hline & & Contro & =25) & Patient & $1=82)$ & p-value \\
\hline Age & Mean (SD) & 51.68 & 14.648 & 53.96 & 10.599 & 0.40 \\
\hline & Range & 32 & 94 & 38 & 75 & \\
\hline SBP & Mean (SD) & 119 & 12.67 & 143.05 & 11.077 & $<0.0001^{* *}$ \\
\hline & Range & 100 & 145 & 130 & 170 & \\
\hline DBP & Mean (SD) & 78 & 9.895 & 91.04 & 8.489 & $<0.0001^{* *}$ \\
\hline & Range & 60 & 90 & 70 & 110 & \\
\hline BMI & Mean (SD) & - & - & 27.65 & 1.672 & - \\
\hline & Range & - & - & 24 & 32 & \\
\hline FBS & Mean (SD) & 110.52 & 35.170 & 174.17 & 70.982 & $<0.0001^{* *}$ \\
\hline & Range & 53 & 189 & 89 & 493 & \\
\hline PPBS & Mean (SD) & - & - & 287.99 & 116.537 & - \\
\hline & Range & - & - & 132 & 594 & \\
\hline Cholesterol & Mean (SD) & 209.28 & 41.449 & 248.80 & 87.017 & $0.033^{*}$ \\
\hline & Range & 135 & 283 & 138 & 640 & \\
\hline LDL & Mean (SD) & 138.05 & 40.228 & 182.33 & 85.281 & $0.014^{*}$ \\
\hline & Range & 70 & 218 & 66 & 596 & \\
\hline HDL & Mean (SD) & 53.16 & 9.472 & 33.96 & 5.069 & $<0.0001^{* \star}$ \\
\hline & Range & 36 & 68 & 22 & 49 & \\
\hline TG & Mean (SD) & 90.36 & 23.738 & 168.51 & 71.727 & $<0.0001^{* \star}$ \\
\hline & Range & 63 & 173 & 60 & 585 & \\
\hline
\end{tabular}

Smoking history as a risk factor did not show any significant difference between MI patients group and control group (Table 2).

Table 2. Risk factors of the studied control and patients

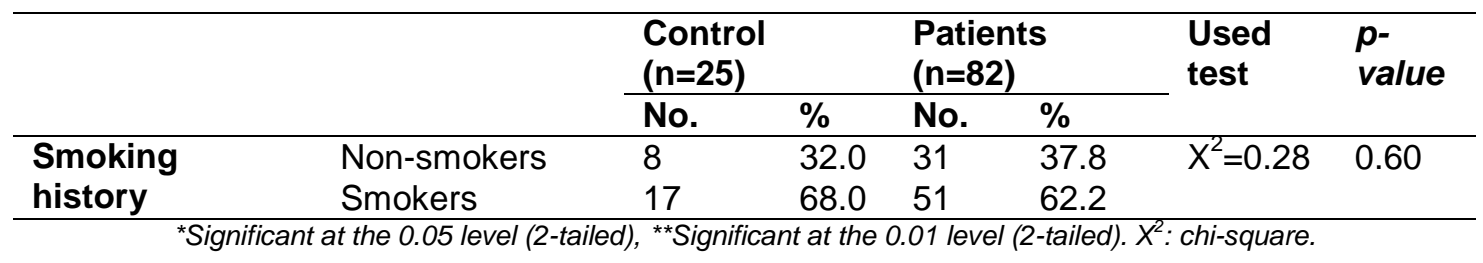

Factor XIII mutations of the studied control and patients in (Table 3) illustrated insignificant difference of wild type GG allele in control group (80\%) versus MI patients group (76.8\%) while the heterozygote polymorphism GT allele in control group was (12\%) versus MI patients group (17.1\%) with insignificant difference and the homozygote TT allele in control group was (8\%) versus MI patients group (6.1\%) with insignificant difference. 
Table 3. Factor XIII mutations of the studied control and patients

\begin{tabular}{llllllll}
\hline & & \multicolumn{2}{l}{ Control $(\mathbf{n}=\mathbf{2 5})$} & \multicolumn{2}{l}{ Patients $(\mathbf{n}=\mathbf{8 2})$} & Used test & p-value \\
\cline { 3 - 6 } & & No. & $\%$ & No. & $\%$ & & \\
\hline Standard & Wild (GG) & 20 & 80.0 & 63 & 76.8 & 0.11 & 0.74 \\
Mutations & Hetero (GT) & 3 & 12.0 & 14 & 17.1 & Fisher & 0.77 \\
& Homo (TT) & 2 & 8.0 & 5 & 6.1 & Fisher & 0.52 \\
\hline & & & &
\end{tabular}

Consistency of observed genotype frequencies with Hardy-Weinberg equilibrium were highly significant and showing more tendency among tested subjects for homozygous alleles than expected alleles $5 \%$ observed versus $1.8 \%$ expected homozygous alleles (Table 4 ).

Table 4. Consistency of observed genotype frequencies with Hardy-Weinberg equilibrium

\begin{tabular}{lcccc}
\hline & Observed & Expected & $\mathbf{X}^{2}$ & $\boldsymbol{p}$-value \\
\hline Homozygote reference: & 63 & 59.8 & 8.22 & $0.004^{* *}$ \\
Heterozygote: & 14 & 20.5 & & \\
Homozygote variant: & 5 & 1.8 & & \\
\hline \multicolumn{4}{c}{ 'Significant at the 0.05 level (2-tailed), ${ }^{* *}$ Significant at the 0.01 level (2-tailed). }
\end{tabular}

The Relative Risk (RR) of FXIII (Val34Leu) for MI patients was tested (estimated as Odds Ratios (OR) and 95\% Confidence Intervals $(\mathrm{Cl})$ ) for those with homozygous allele were compared with the risk for those who carried the wild type allele. With total of (82) cases, it is estimated for a statistical power of $80 \%$, OR $\geq 2$ will be significant at the $5 \%$ level. Factor XIII polymorphism showed insignificant $\mathrm{OR}$ and $\mathrm{Cl}$ values indicating no effect as a risk factor for MI patients in recruited subjects and only HDL and FBS were risk factors with significant OR and $\mathrm{Cl}$ values (Table 5).

Table 5. Estimate, standard error (SE), odds ratio (OR), and confident intervals (CI) among the studied variables

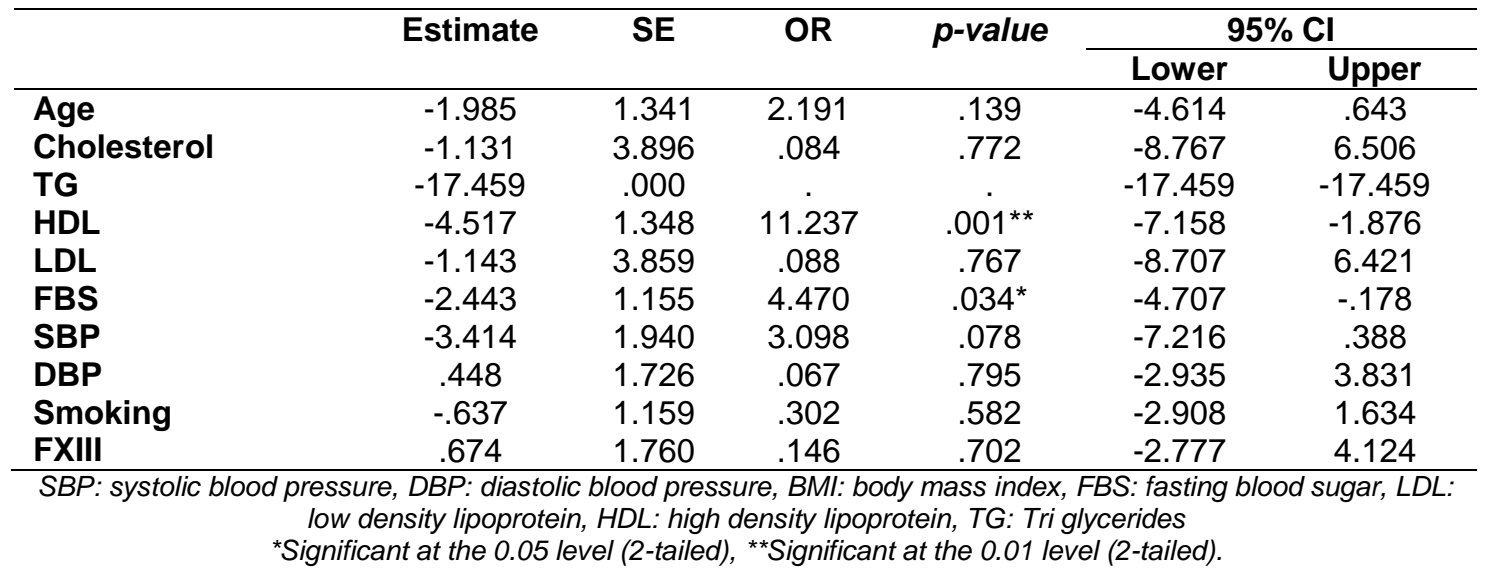

Inter-correlations among the studied variables using Pearson correlation coefficient showed insignificant correlation between FXIII Val34Leu polymorphism and MI patients while all other tested predictors and risk factors such as blood sugar, high cholesterol and lipids, blood pressure and smoking were highly significant for MI. The most interesting outcome represented in this statistical test, there is no Inter-correlations significance between age and FXIII Val34Leu polymorphism (Table 6). 
Table 6. Means, standard deviations (SD), and inter-correlations among the studied variables

\begin{tabular}{|c|c|c|c|c|c|c|c|c|c|c|c|c|c|c|}
\hline & & Mean & SD & 1 & 2 & 3 & 4 & 5 & 6 & 7 & 8 & 9 & 10 & 11 \\
\hline 1-Age & $\begin{array}{l}\text { Pearson } \\
\text { Correlation } \\
\text { P-value }\end{array}$ & 53.43 & 11.634 & & & & & & & & & & & \\
\hline 2-Cholesterol & $\begin{array}{l}\text { Pearson } \\
\text { Correlation } \\
\text { P-value }\end{array}$ & 239.57 & 80.358 & $\begin{array}{l}-.096 \\
.323\end{array}$ & & & & & & & & & & \\
\hline 3-TG & $\begin{array}{l}\text { Pearson } \\
\text { Correlation } \\
\text { P-value }\end{array}$ & 150.25 & 71.854 & $\begin{array}{l}-.162 \\
.095\end{array}$ & $\begin{array}{l}.189 \\
.051\end{array}$ & & & & & & & & & \\
\hline 4-HDL & $\begin{array}{l}\text { Pearson } \\
\text { Correlation } \\
\text { P-value }\end{array}$ & 38.45 & 10.322 & $\begin{array}{l}. .104 \\
.287\end{array}$ & $\begin{array}{l}. .195^{\star} \\
.044\end{array}$ & $\begin{array}{l}-.434^{\pi \pi} \\
.000\end{array}$ & & & & & & & & \\
\hline 5-LDL & $\begin{array}{l}\text { Pearson } \\
\text { Correlation } \\
\text { P-value }\end{array}$ & 171.97 & 79.247 & $\begin{array}{l}-.060 \\
.539\end{array}$ & $.979^{* x}$ & .212 & $\begin{array}{l}-.261^{\star *} \\
.007\end{array}$ & & & & & & & \\
\hline 6-FBS & $\begin{array}{l}\text { Pearson } \\
\text { Correlation } \\
\text { P-value }\end{array}$ & 159.30 & 69.731 & $\begin{array}{l}.155 \\
.110\end{array}$ & $\begin{array}{l}.092 \\
.343\end{array}$ & $\begin{array}{l}.498^{\star *} \\
.000\end{array}$ & $\begin{array}{l}-.329^{* *} \\
.001\end{array}$ & $\begin{array}{l}.064 \\
.513\end{array}$ & & & & & & \\
\hline 7-SBP & $\begin{array}{l}\text { Pearson } \\
\text { Correlation } \\
\text { P-value }\end{array}$ & 137.43 & 15.317 & $\begin{array}{l}.319^{* *} \\
.001\end{array}$ & $\begin{array}{l}.071 \\
.469\end{array}$ & $\begin{array}{l}.000 \\
.370^{\star *} \\
.000\end{array}$ & $\begin{array}{l}-.610^{* *} \\
.000\end{array}$ & .094 & $\begin{array}{l}.435^{* *} \\
.000\end{array}$ & & & & & \\
\hline 8-DBP & $\begin{array}{l}\text { Pearson } \\
\text { Correlation } \\
\text { P-value }\end{array}$ & 87.99 & 10.390 & $\begin{array}{l}.212^{*} \\
.028\end{array}$ & $\begin{array}{l}.151 \\
.119\end{array}$ & $\begin{array}{l}.347^{* *} \\
.000\end{array}$ & $\begin{array}{l}-.493^{* *} \\
.000\end{array}$ & $\begin{array}{l}.163 \\
.094\end{array}$ & $\begin{array}{l}.426^{\star *} \\
.000\end{array}$ & $\begin{array}{l}.842^{* *} \\
.000\end{array}$ & & & & \\
\hline 9-Smoking & $\begin{array}{l}\text { Pearson } \\
\text { Correlation } \\
\text { P-value }\end{array}$ & 15.16 & 17.190 & $\begin{array}{l}.216 \\
.025\end{array}$ & -.014 & $.317^{\pi \times}$ & $-.336^{\pi x}$ & .010 & $.377^{x \pi}$ & $.457^{\pi \times}$ & $.377^{\pi x}$ & & & \\
\hline 10-FXIII & $\begin{array}{l}\text { Pearson } \\
\text { Correlation }\end{array}$ & .38 & .748 & $\begin{array}{l}.025 \\
.059\end{array}$ & $\begin{array}{l}.886 \\
.041\end{array}$ & $\begin{array}{l}.001 \\
.030\end{array}$ & $\begin{array}{l}.000 \\
-.098\end{array}$ & $\begin{array}{l}.921 \\
.078\end{array}$ & $\begin{array}{l}.000 \\
.001\end{array}$ & $\begin{array}{l}.000 \\
.037\end{array}$ & $\begin{array}{l}.000 \\
.051\end{array}$ & .063 & & \\
\hline 11-MI & $\begin{array}{l}\text { P-value } \\
\text { Pearson } \\
\text { Correlation }\end{array}$ & .77 & .425 & $\begin{array}{l}.546 \\
.083\end{array}$ & $\begin{array}{l}.672 \\
.209\end{array}$ & $\begin{array}{l}.762 \\
.462^{\pi \pi}\end{array}$ & $\begin{array}{l}.314 \\
-.791^{* *}\end{array}$ & $\begin{array}{l}.423 \\
.238^{*}\end{array}$ & $\begin{array}{l}.992 \\
.388^{\pi *}\end{array}$ & $\begin{array}{l}.702 \\
.668^{\star \pi}\end{array}$ & $\begin{array}{l}.599 \\
.533^{x \times}\end{array}$ & $\begin{array}{l}.521 \\
.467^{\pi \times}\end{array}$ & .047 & \\
\hline & P-value & & & .393 & .031 & .000 & .000 & .014 & .000 & .000 & .000 & .000 & .632 & \\
\hline
\end{tabular}

SBP: systolic blood pressure, DBP: diastolic blood pressure, BMl: body mass index, FBS: fasting blood sugar, LDL: low density lipoprotein, HDL: high density lipoprotein, TG: Tri glycerides

*Significant at the 0.05 level (2-tailed), ${ }^{*}$ Significant at the 0.01 level (2-tailed). 
Regression analysis model showed insignificant effect of FXIII polymorphism in MI patients and only HDL, smoking and SBP have significant risk for MI patients. (Table 7)

Table 7. Hierarchical regression model for MI occurrence and other studied variables in the studied populations

\begin{tabular}{|c|c|c|c|c|c|}
\hline & B & SE B & $\beta$ & $t$ & $p$-value \\
\hline (Constant) & .662 & .365 & & 1.815 & .073 \\
\hline Age & -.003 & .002 & -.083 & -1.345 & .182 \\
\hline Cholesterol & .002 & .002 & .427 & 1.255 & .212 \\
\hline TG & 3.804 & .000 & .001 & .008 & .994 \\
\hline HDL & -.024 & .003 & -.591 & -7.099 & $<0.0001^{\star *}$ \\
\hline LDL & -.002 & .002 & -.356 & -1.038 & .302 \\
\hline FBS & .000 & .000 & .023 & .334 & .739 \\
\hline SBP & .009 & .003 & .334 & 2.819 & $.006^{\star *}$ \\
\hline DBP & -.004 & .004 & -.103 & -1.003 & .318 \\
\hline Smoking & .004 & .002 & .175 & 2.732 & $.007^{* *}$ \\
\hline \multirow[t]{4}{*}{ FXIII polymorphism } & -.008 & .031 & -.014 & -.259 & .796 \\
\hline & & .850 & & & \\
\hline & $\mathbf{R}^{2}$ & .723 & & & \\
\hline & Adjusted $\mathbf{R}^{2}$ & .694 & & & \\
\hline
\end{tabular}

\section{DISCUSSION}

Genotype analysis for FXIII Val34Leu was carried out in two well characterized subjects groups where the diagnostic criteria of MI were strict.

Cerebrovascular, coronary artery disease (CAD) and myocardial infarction shares many pathophysiologic mechanisms, several reports suggested that the FXIII-A 34Leu allele provides protection against them and were associated with a decreased risk of myocardial infarction in several different human studies [22-30].

The effect of polymorphism in FXIII-A 34Leu allele might be variable in different populations according to the levels of fibrinogen and thrombin in plasma. In relation, a meta- analysis of the published data demonstrated a moderate, but statistically significant protection by the Leu34 allele [31]. Some results suggest that a significant gene-covariate interaction exists between the FXIII-A Val34Leu genotype and fibrinogen levels [32,33].

The presence of the Val34Leu polymorphism increases the rate of FXIII activation by thrombin. In synthetic peptides, a significant variation in rates of activation has been demonstrated among different FXIII structures [34]. Studies have shown that the Leu34 allele variant promotes accelerated cleavage of the activation peptide once activated by thrombin [14]. The presence of the FXIII Val34Leu polymorphism has a significant effect on fibrin clot structure. Wartiovaara et al. have shown that fibrin $y$-chain dimerization and a polymerization are enhanced in the presence of FXIII Val34Leu. In these experiments using low thrombin concentrations $(0.5 \mathrm{U} / \mathrm{mL}), \mathrm{Y}-\mathrm{y}$ dimers were present at $2.5 \mathrm{~min}$ in the presence of all polymorphisms, but the FXIII 34Leu mutants accumulated the dimers faster and the $Y$ monomers disappeared faster compared to wild type controls [16]. 
Val34Leu polymorphism affects the function of FXIII by increasing the rate of FXIII activation with thrombin, which results in an increased and faster rate of fibrin stabilization $[4,30]$. This effect appears dependent on the genetic dose. Thus, the Leu/Leu genotype is associated with elevated activity of FXIII, whereas heterozygous carriers exhibit intermediate activity $[14,18]$. Although Frequency of the Leu34 allele in a Chinese Han population was lower than Caucasian populations (2.5 vs $20.4 \%-28.3 \%$ ) FXIII-A Leu34 allele may contribute to a protective effect against the development of $\mathrm{MI}$ and this might indicate the Leu34 allele protective effect has no relation with its frequency [35].

In contrary, many other studies focusing on polymorphisms of these coagulation factors did not find an association with cardiovascular disease (CVD) in Italy and USA [36,37]. Several multi-locus candidate gene polymorphisms for other coagulation factors appear not, or only weakly, associated with the risk of first myocardial infarction (MI) in Netherlands and USA $[38,39]$. A study on Asian patients undergoing coronary angiography in the United Kingdom did not demonstrate an association between the Val34Leu FXIII polymorphism and a history of myocardial infarction and the published results came from Italy, USA and Spain [40]. As part of the negative studies came from Mediterranean countries, it was proposed that in these populations, well protected against CAD by environmental factors, the Leu34 allele does not provide any further protection [15]. Genetic analysis was performed on 585 Caucasian; unrelated subjects representative of the general population of Mediterranean Sea area and FXIII Val34Leu was not associated with reduced premature myocardial infarction [17].

In addition, many studies in Hungary, Italy and a meta- analysis in Canada have not found this association with $\mathrm{MI}$ and reported no effect of this polymorphism on the risk of deep venous thrombosis [41-43]. Pools from different geographical areas of Finland were genotyped and no significant differences in the allele frequencies were observed except in the Eastern Kainuu area, an area with an increased risk of mortality from coronary artery disease (CAD) [44]. FXIII Val34Leu genetic variant is strongly associated with resistance to fibrinolysis relevant to lytic therapy, but neither relates to premature CAD nor to recurrent acute coronary events [45].

The results of the current study showed that FXIII Val34Leu polymorphism has no effect on $\mathrm{MI}$ or hypertension in Egyptian patients. The current results of this study is in agreement with the various published data from Mediterranean Sea area, USA, Spain, Italy, Netherlands, Hungary and Canada [15,17,35-37,39-43]. The discrepancy in this study with other studies might be explained by the hypothesis that role of this polymorphism in thrombosis is a population-dependant [17].

\section{CONCLUSION}

FXIII Val34Leu polymorphism has no effect in the recruited Egyptian MI patients which is similar to most of the published studies considered the Mediterranean Sea area populations.

\section{CONSENT}

Written consent was taken from all participants as a routine admission protocol, as the hospital is a charge-free university educational hospital and all patients were informed that their diagnosis and collected biological samples during diagnosis could be used anonymously for education and research purposes. 


\section{ETHICAL APPROVAL}

This work was approved by the ethical committee and all Patients were recruited from consecutive admission to the coronary care unit, Suez Canal University Hospital, Ismailia, Egypt. All prerequisites demanded by the Faculty research ethical committee were considered and fulfilled for our patients and the whole protocol without any invasive techniques or methods was approved from Faculty research ethical committee. All blood samples were drawn during the patients' examination by the Cardiology specialists in outpatient clinic.

\section{ACKNOWLEDGEMENTS}

This study was not supported by any grants and all its costs were covered by the authors. We are appreciating the deep cooperation and help from Cardiology department, Faculty of Medicine, Suez Canal University.

\section{COMPETING INTERESTS}

Authors did not receive any financial aid or fund from any source or funding agents and all the work cost were covered by the authors.

\section{REFERENCES}

1. Danesh J, Lewington S, Thompson SG, et al. Plasma fibrinogen level and the risk of major cardiovascular diseases and nonvascular mortality: an individual participant meta-analysis. JAMA. 2005;294:1799-809.

2. Davies MJ, Thomas AC. Plaque fissuring-the cause of acute myocardial infarction, sudden ischaemic death, and crescendo angina. Br Heart J. 1985;53:363-73.

3. Hamsten A. The hemostatic system and coronary heart disease. Thromb Res. 1993;70:1-38.

4. Ariëns RA, Philippou H, Nagaswami C, et al. The factor XIII V34L polymorphism accelerates thrombin activation of factor XIII and affects cross-linked fibrin structure. Blood. 2000;96:988-95.

5. Bereczky Z, Katona É, Muszbek L. Fibrin stabilization (factor XIII), fibrin structure and thrombosis. Pathophysiol Haemost Thromb. 2004;33:430-7.

6. Greenberg CS, Sane DC, Lai T. Factor XIII and fibrin stabilization. In: Colman RW, Marder VJ, Cloves AW, George JN, Goldhaber SZ, editors. Hemostasis and thrombosis. $5^{\text {th }}$ edition. Philadelphia: Lippincott Williams and Wilkins. 2006;317-34.

7. Mosesson MW, Siebenlist KR, Hernandez I, et al. Evidence that alpha2-antiplasmin becomes covalently ligated to plasma fibrinogen in the circulation: a new role for plasma factor XIII in fibrinolysis regulation. Journal of Thrombosis Haemostasis. 2008;6:1565-1570.

8. Muszbek L, Bereczky Z, Bagoly Z, et al. Factor XIII, a coagulation factor with multiple plasmatic and cellular functions. Physiol Rev. 2011;91:931-72.

9. Marenberg ME, Risch N, Berkman LF, et al. Genetic susceptibility to death from coronary heart disease in a study of twins. N Engl J Med. 1994;330:1041-46.

10. Lane DA, Grant PJ. Role of hemostatic gene polymorphisms in venous and arterial thrombotic disease. Blood. 2000;95:1517-32. 
11. Board PG, Webb GC, McKee J, et al. Localization of the coagulation factor XIII A subunit gene $(\mathrm{F} 13 \mathrm{~A})$ to chromosome bands 6p24-p25. Cytogenet Cell Genet. 1988;48:25-7.

12. Mikkola H, Muszbek L, Laiho E, et al. Molecular mechanism of a mild phenotype in coagulation factor XIII (FXIII) deficiency: a splicing mutation permitting correct splicing of FXIII A-subunit mRNA. Blood. 1997a;89:1279-87.

13. Mikkola H, Muszbek L, Haramura G, et al. Molecular mechanisms of mutations in factor XIII A-subunit deficiency: in vitro expression in COS-cells demonstrates intracellular degradation of the mutant proteins. Thromb Haemostasis. 1997b;78:1068-74.

14. Kohler HP, Stickland MH, Ossei-Gernig N, et al. Association of a common polymorphism in the factor XIII gene with myocardial infarction. Thromb Haemost. 1998;79:8-13.

15. Muszbek L. Deficiency causing mutations and common polymorphisms in the factor XIII-A gene. Thromb Haemost. 2000;84:524-7.

16. Wartiovaara $\mathrm{U}$, Mikkola $\mathrm{H}$, Szoke $\mathrm{G}$, et al. Effect of Val34Leu polymorphism on the activation of the coagulation factor XIII-A. Thromb Haemost. 2000;84:595-600.

17. Roldan V, Corral J, Marin F, et al. Role of factor XIII Val34Leu polymorphism in patients $<45$ years of age with acute myocardial infarction. Am J Cardiol. 2003;91:1242-5.

18. Kangsadalampai S, Board PG. The Val34Leu polymorphism in the A subunit coagulation factor XIII contributes to the large normal range in activity and demonstrates that the activation peptide plays a role in catalytic activity. Blood. 1998;92:2766-70.

19. Thygesen K, Alpert JS, White HD. Universal definition of myocardial infarction. Eur. Heart J. 2007;28:2525-38. PMID: 17951287

20. Tàssies $\mathrm{D}$, Roque $\mathrm{M}$, Monteagudo $\mathrm{J}$, et al. Thrombin-activatable fibrinolysis inhibitor genetic polymorphisms as markers of the type of acute coronary syndrome. Thromb. Res. 2009;124:614-18. DOI: 10.1016/j.thromres.2009.07.004

21. Chobanian AV, Bakris GL, Black HR, et al. Seventh report of the joint national committee on prevention, detection, evaluation and treatment of high blood pressure JNC 7. Hypertension. 2003;42:1206-52. PMID: 14656957

22. Franco RF, Pazin-Filho A, Tavella AH, et al. Factor XIII Val34Leu and the risk of myocardial infarction. Haematologica. 2000;85:67-71.

23. Gemmati $D$, Serino $M$, Ongaro $A$, et al. A common mutation in the gene for coagulation factor XIII-A (Val34Leu): a risk factor for primary intracerebral hemorrhage is protective against atherothrombotic diseases. Am J Hematol. 2001;67:183-8.

24. Kakko S, Elo T, Tapanainen JM, et al. Polymorphisms of genes affecting thrombosis and risk of myocardial infarction. Eur J Clin Invest. 2002;32:643-8.

25. Chatterjee T, Schröder V, Windecker S, et al. Venous and intracoronary factor XIII Asubunit antigen and activity levels are not associated with extent of coronary artery disease. J Thromb Haemost. 2003;1:861-3.

26. Slowik A, Dziedzic T, Pera J, et al. Coagulation factor XIII Val34Leu polymorphism in patients with small vessel disease or primary intracerebral hemorrhage. Cerebrovasc Dis. 2005;19:165-70.

27. Hanser VS, Diz-Kucukkaya R, Bilge AK, et al. The association between factor XIII Val34Leu polymorphism and early myocardial infarction. Circ J. 2006;70:239-42. 
28. Akar N, Dönmez B, Deda G. FXIII gene Val34Leu polymorphism in Turkish children with cerebral infarct. J Child Neurol. 2007;22:222-4.

29. Smith NL, Bis JC, Biagiotti S, et al. Variation in 24 hemostatic genes and associations with non-fatal myocardial infarction and ischemic stroke. J Thromb Haemost. 2008;6:45-53.

30. Shemirani AH, Pongrácz E, Antalfi B, et al. Factor XIII A subunit Val34Leu polymorphism in patients suffering atherothrombotic ischemic stroke. Thromb Res. 2010;126:159-62.

31. Vokó Z, Bereczky Z, Katona E, et al. Factor XIII Val34Leu variant protects against coronary artery disease. A meta-analysis. Thromb Haemost. 2007;97:458-63.

32. Boekholdt SM, Sandhu MS, Wareham NJ, et al. Fibrinogen plasma levels modify the association between the factor XIII Val34Leu variant and risk of coronary artery disease: the EPIC-Norfolk prospective population study. J Thromb Haemost. 2006;4:2204-9.

33. Bereczky Z, Balogh E, Katona É, et al. Elevated factor XIII level is associated with an increased risk of myocardial infarction in women. Haematologica. 2007;92:287-8.

34. Trumbo TA, Maurer MC. Val34I and V34A substitutions within the factor XIII activation peptide segment (28-41) affect the interactions with the thrombin active site, Thromb Haemost. 2003;89:647-53.

35. Guodong J, et al. Coagulation factor XIII-A Val34Leu polymorphism and the risk of coronary artery disease and myocardial infarction in a Chinese Han population. Clin Appl Thromb Hemost. 2011;17:208-13.

36. Durante-Mangoni E, Davies GJ, Ahmed N, et al. The prothrombin G20210A polymorphism in patients with myocardial infarction. Blood Coagul Fibrinolysis. 2002;13:603-8.

37. Smiles AM, Jenny NS, Tang $Z$, et al. No association of plasma prothrombin concentration or the G20210A mutation with incident cardiovascular disease: results from the Cardiovascular Health Study. Thromb Haemost. 2002;87:614-21.

38. Boekholdt SM, Bijsterveld NR, Moons AH, et al. Genetic variation in coagulation and fibrinolytic proteins and their relation with acute myocardial infarction: a systematic review. Circulation. 2001;104:3063-8.

39. Zee RY, Cook NR, Cheng S, et al. Multi-locus candidate gene polymorphisms and risk of myocardial infarction: a population-based, prospective genetic analysis. J Thromb Haemost. 2006;4:341-8.

40. Warner D, Mansfield MW, Grant PJ. Coagulation factor XIII and cardiovascular disease in UK Asian patients undergoing coronary angiography. Thromb Haemost. 2001;85:408-11.

41. Balogh I, Szoke G, Karpati L, et al. Val34Leu polymorphism of plasma factor XIII: biochemistry and epidemiology in familial thrombophilia, Blood. 2000;96:2479-86.

42. Margaglione M, Bossone A, Brancacccio V, et al. Factor XIII Val34 Leu mutation and risk of deep vein thrombosis. Thromb Haemost. 2000;84:1118-19.

43. Wells $\mathrm{P}$, Anderson J, Scarvelis $\mathrm{D}$, et al. Factor XIII Val34Leu variant is protective against venous thromboembolism: a HuGE review and metaanalysis. Am J Epidemiol. 2006;164:101-9. 
44. U. Wartiovaara a, M. Perolab1, H. Mikkola a, K. To"tterman c, V. Savolainen d, A. Penttila d, P.J. Grant e MJTc, E. Vartiainen f, PJ. Karhunen g, L. Peltonen b, A. Palotie a, Association of FXIII Val34Leu with decreased risk of myocardial infarction in Finnish males. Atherosclerosis. 1999;142:295-300.

45. Silvain J, et al. Altered fibrin clot structure/function and FXIII Leu34 genetic variant in patients with premature coronary artery disease. Thromb Haemost. 2011;106:511-20.

(C) 2013 Amin et al.; This is an Open Access article distributed under the terms of the Creative Commons Attribution License (http://creativecommons.org/licenses/by/3.0), which permits unrestricted use, distribution, and reproduction in any medium, provided the original work is properly cited.

Peer-review history:

The peer review history for this paper can be accessed here: http://www.sciencedomain.org/review-history.php?iid=205\&id=12\&aid=1753 